(Litors r r $\begin{array}{r}2018 \text { Volume 24(1): 253-270 } \\ \text { doi:10.3846/20294913.2016.1212438 }\end{array}$

\title{
A COMPARATIVE ANALYSIS OF DEVELOPMENT IN SOUTHEAST EUROPEAN COUNTRIES
}

\author{
Sandra JEDNAK, Dragana KRAGULJ, Milica BULAJIC \\ Faculty of Organizational Sciences, University of Belgrade, Jove Ilica 154, 11000 Belgrade, Serbia
}

Received 20 March 2014; accepted 21 February 2015

\begin{abstract}
There are different kinds of indicators which measure levels of development. The use of varying methods could alter the ranking of a particular country. In this paper, Southeast European countries are ranked according to the World Bank, the UNDP and the I-distance method. The aim of the paper is to provide a comparison between the ranking results obtained with those methods for the period 2007-2012. The principal objective of the study is the ranking of SEE countries using the I-distance technique - a multivariate statistical method for ranking entities - and to discover whether this method gives a better ranking of countries than income per capita and the HDI. To answer this question, similar variables of economic development are used within the research methods. Due to the observed period, some government finance variables are also included. Despite certain limitations, such as lack of data for SEE countries, the results show that the ranks of countries are highly similar regardless of the method used. Nevertheless, there are some differences in the countries' rankings in some years: there are small differences from year to year both in terms of HDI and GNI per capita. However, the I-distance method shows greater differences between countries.
\end{abstract}

Keywords: economic development, Southeast European countries, ranking, comparative analysis, I-distance method.

JEL Classification: O11, O57, P20, P21, C10, C38.

\section{Introduction}

There is diversity among countries and it is usual to classify and rank them. Many research studies measure and rank countries (Malul et al. 2009; Eckehard 2011; Stiglitz et al. 2009a; Radojicic et al. 2012; Høyland et al. 2012; Pérez-Ortiz et al. 2014; Khayyat, Lee 2016) using different methods based on economic, political, environmental, social and/or many other indicators. Rank can show and measure a country's level of economic development. International organisations such as the World Bank, UNDP, IMF and OECD have their own country classification system through which they rank countries using their own set

Corresponding author Sandra Jednak

E-mail: sjednak@fon.bg.ac.rs 
of indicators. The classic indicators of welfare and standard of living which are still most frequently used are the Gross Domestic Product (GDP) and GDP per capita. However, since these two indicators have some limits and cannot be the only indicators of wealth new ones should be introduced (Cachanosky 2009; Davidson 2000; Dowrick et al. 2003; Kubiszewski et al. 2013). Some of the problems related to the GDP are reliability of data, income distribution, and the fact that the informal economy is not included and not all aspects of human development are measured (Stiglitz et al. 2009b; van den Bergh 2009; Norberg 2010). In addition to the GDP, the Human Development Index (HDI) is also one of the most widely used measures of human welfare. Still, the HDI is criticised because it does not take into account inequality within countries (Sagar, Najam 1998; Grimm et al. 2008; Blancard, Hoarau 2013; Wu et al. 2014; Luque et al. 2016). Furthermore, researchers use other measures of economic development, such as economic activity per sector, health care, literacy, the number of material possessions per capita, etc. The ways of measuring economic performance have been constantly changing and improving. As a result, new methods, approaches and indicators have been developed.

The aim of this paper is to rank countries using the I-distance method - another, lessknown method introduced by Ivanovic (1977) - which applies selected socio-economic indicators, such as GDP per capita, general government gross debt, general government net lending/borrowing, total debt services, inflation, unemployment, internet users, life expectancy at birth and mean years of schooling of adults. Rankings will be made for the selected Southeast European countries: Albania, Bosnia and Herzegovina, Bulgaria, Croatia, Macedonia, Moldova, Montenegro, Romania and Serbia, for the period 2007-2012. These countries were chosen because they have carried out economic reforms in order to become market economies and members of the EU. Governments and international organisations could contribute to their economic development by obtaining capital, foreign financial aid, donations, loans and debt forgiveness. Their allocation of funding to these countries is based on their level of development. Each organisation and government has its own criteria for ranking economies. The purpose of this research is to compare three methods of ranking countries and to discover whether and to what extent the I-distance method gives different rankings for countries when compared to income per capita and the HDI. The focus of this study is a comparison between the I-distance method ranking and that according to the World Bank criteria of income per capita and the UNDP Human Development Index. The results show that the countries' rankings based on the I-distance method do not significantly differ from those according to international organisations.

The paper is organised as follows. The next section surveys empirical literature on the background to economic development in the countries under analysis. The methodology section (Section 2) describes reviews and analyses of the existing classification and rankings of these countries by the World Bank, the Human Development Index, and the I-distance method. Section 3 compares the level of development and the rankings of the selected Southeast European countries according to GNI per capita, the HDI and the I-distance method, while the last section concludes and summarises the research results. 


\section{Background to the economic development of the selected Southeast European countries}

During the last decade, the Southeast European region has been implementing economic and other reforms in order to establish a stable and market-based economy. However, achieving this aim requires a certain amount of time. The region is diverse and complex, at various stages of development, and characterised by relatively low income per capita (Bartlett 2008; Petrakos et al. 2011). Among the economies, various initial conditions, economic policies, reforms, changes and factors are performed differently (de Melo et al. 1997; Acemoglu 2010; BenYishay, Grosjean 2014). Macroeconomic indicators show to what extent the reforms have been implemented, whether the selected reforms have been adequate for a particular economy and how many of them are inappropriate, inadequate and/or insufficient. Some countries of the region are reaching macroeconomic stability, liberalisation and openness to the global market, while others are not. The initial conditions significantly affect the achievement of good economic performance (de Melo et al. 1997; Delgado et al. 2012). However, Falcetti et al. (2006) state that although the benefits of the initial conditions decline over time, a fiscal surplus remains one of the most important factors for obtaining growth. Structural surplus rules may also improve welfare (Kumhof, Laxton 2013). The economic growth and development of most SEE countries has depended on international capital inflows and on the pace of industrial and social transformation (Babanassis 2003; Iwasaki, Tokunaga 2014). In addition, Josifidis et al. (2012) find that economic growth is determined by macroeconomic stabilisation and structural reforms, but also by foreign direct investment and economic integrations within emerging European countries.

All the observed countries (with the exception of Bulgaria, Romania and Croatia) are still considered to be undergoing a transition period. Transition is a multidimensional process which encapsulates many objectives that must be achieved, such as the liberalisation of the market and prices, the privatisation of enterprises, domestic and foreign trade liberalisation, reforms of the banking system and capital market; the creation, harmonisation, and strengthening of those institutions and policies relevant to the functioning of a market economy; the creation of conditions for attracting foreign direct investment which will enable long-term economic growth, the formulation of policies of openness and credibility, the strengthening of laws and legislative order, reforms within the sphere of politics, etc. (Delic, Kragulj 2005). Accordingly, the main transition goals are of both an economic and political nature, i.e. they tend to not only increase economic efficiency and establish a stable democracy, but they are also likely to be included in European integration processes on these bases. Transition processes can be illustrated by the Latin alphabet letter »U«(Blanchard 1997). Namely, during the initial phase of reforms, all these transition economies were characterised by negative trends in all economic indices, such as a sharp decline in gross domestic product, a decline in industrial production, an increase in unemployment, high inflation and a fiscal deficit (Kragulj 2005). All this happened, among other things, because of outdated equipment, lack of capital, insufficiently trained and qualified personnel, and overemployment in all enterprises (EBRD Transition Report 2006). However, things began to change substantially in 2000 and the countries of this 
region showed significant progress in the implementation of reforms. All the countries experienced a relatively high rate of economic growth from mid-2007 due to the growth of domestic demand conditioned by the expansion of domestic loans in the private sector and net exports. Furthermore, high growth rates were the consequence of European and global integration in the areas of trade, investments and finance flows. However, the progressive growth of loans subsequently dropped due to the intensification and escalation of the global crisis. Most countries depend on foreign financial aid and loans. Fewer loans resulted in a drop in investments and domestic demand and, consequently, in a fall in exports. All these negative changes caused economic activities to slow down, first in 2008 and then in 2009. The IMF suggested conducting expansive monetary policy, cutting interest rates, and expanding fiscal policy through fiscal stimulus. Monetary policy was to be focused on preventing and limiting currency appreciation, while expansive fiscal policy would be focused on greater stimulation of aggregate demand, especially in those cases where the economy is relatively closed towards trade flows (Nuti 2009).

There is also a noticeable macroeconomic imbalance in the region, especially in the balance of trade or the current account of the balance of payments. As for fiscal policies, there were some improvements. In the period between 2003 and 2005, the fiscal deficit for the entire region was at its lowest since the beginning of the transition process. During that period, certain countries (Serbia, Bosnia and Herzegovina, Montenegro and Bulgaria) achieved a surplus balance in their fiscal budgets. Although fiscal policies improved in some countries, all the observed countries suffered a fiscal deficit in the period from 2008 to 2012 . There is a need to continue reforms and to achieve certain objectives, such as fiscal consolidation, changes in the structure of fiscal revenues and expenditures, decreasing such high unemployment, the reduction of poverty and an increase in the standard of living (Sanfey, Teksoz 2007). In addition, there is an intensive inflation process characterised by dynamism and diversity in the factors that have caused it. All types of inflation can be said to be present: from budgetary, credit, and cost-push to structural and systematic inflation. The burning issues, not only in the countries of this region, but also in Europe (and wider), are the increase in unemployment and, consequently, the decrease in employment. Such high unemployment rates are, above all, the consequence of the insufficiently-developed economy and structural changes in production. The highest unemployment rates have been recorded in Bosnia and Herzegovina (above 27\%) and Serbia (about 25\%). Such disadvantageous macroeconomic trends result in insufficient foreign capital inflow. Both theory and some studies show that FDI has a positive influence on economic growth whether directly or indirectly (Damijan et al. 2003; Kovacevic 2004; Xu, Wang 2007; Kostoska, Mitrevski 2008; Radulescu 2012; Giroud et al. 2012; Iamsiraroj, Ulubasoglu 2015). Southeast European countries that are still in transition cannot achieve production and employment growth, influx of new technologies, international payment balancing, etc., without FDI.

According to the aforementioned, there are obviously various levels of economic development in the region and countries' rankings can be done. Furthermore, the aspects of development have improved and indicators have changed from accumulated capital per worker, to technological differences, to innovations (Fagerberg, Srcholec 2008). 


\section{Methodology}

The purpose of this research is to compare three methods of ranking countries - the World Bank, the UNDP and the I-distance methods. The income per capita and HDI are widely used indicators for measuring economic development. Still, these indicators do not represent the level of human welfare quite adequately. Therefore, in this study, the level of development and the corresponding ranks will be calculated by applying the I-distance method on several socio-economic indicators. These indicators were chosen based on their similarity to the HDI and income per capita. Furthermore, due to the observed period, the period following the economic crisis, a few indicators of government finance were also included. The focus of the research is to compare the ranks based on the I-distance method with those obtained in the ranking processes based on the World Bank criteria of income per capita and the UNDP Human Development Index.

Although standard indicators of development and ranking methods do exist, the I-distance method is used in order to highlight the differences between countries and the dynamic of change within a particular observational period. Through the use of the I-distance method, it is possible to arrive at more detailed results which pinpoint the similarities and differences between countries within a given time frame. The dynamic of change within the obtained rankings, i.e. the results based on income per capita and the HDI, are expected to be less evident than those gained with the use of the I-distance method.

It is also important to note that the I-distance method is simple to implement. The method is not overly time-consuming, either in terms of preparation or realization. Furthermore, the I-distance method overcomes the problem of diverse variables as it synthesizes a large number of variables (indicators) into one value (indicator). One of the advantages of the use of the I-distance method is its objectivity, free from the subjective assignment of weighting coefficients with individual indicators. The use of statistical methods creates a unique, all-encompassing indicator of development which is seen and described across several characteristics. However, this fact may present one of the disadvantages of the Idistance method as in some studies it is important to highlight the greater significance of certain individual indicators. This shortcoming is overcome through the selection of an appropriate ordering of the variables that are used, which this work has ensured.

Within this research, the I-distance method will serve to shed light on the differences between the observed countries, and, through analysis of the original data, will pinpoint what brought about such results.

\subsection{The World Bank classification - income per capita}

There are various socio-economic indicators to measure economic development. Different international institutions and organisations have developed their own systems for the classification and ranking of countries. The World Bank developed country classification based on geographic region. Both developing and underdeveloped countries are mainly those with low and middle incomes, while developed countries have high incomes. Groups of countries are established according to the World Bank (2012) GNI per capita: low income, $\$ 1,035$ or less; lower middle income, $\$ 1,036$ - $\$ 4,085$; upper middle income, $\$ 4,086$ - 
$\$ 12,615$; and high income, $\$ 12,461$ or more. The main indicator for ranking countries is the GDP (or GNP) per capita and the economic differences among regions and countries can be presented based on it (Tvrdon, Skokan 2011). This indicator shows the standard of living. In addition, the World Bank has a number of other indicators to demonstrate country development. The World Development Indicators (WDI) database contains more than 1000 indicators covering 216 countries in the period from 1960 to 2012 (The World Bank 2012).

Although the makers of economic policy find data based on the GDP (or GNP) per capita and other aggregate measures enormously important, easily measured and applicable to all countries in the world, they have certain drawbacks as the criteria for the welfare of a macro economy (Michaelson et al. 2009; Kragulj 2012; Aruoba et al. 2016). Above all, GDP: 1. does not envisage the goals of production and the quality of economy growth, 2. does not include the value of goods and services that have not been paid, 3. does not provide any information on the quality of life (e.g. the environment, non-material needs, free time, etc.), 4. does not provide any information on economic imbalance (allocation imbalance, participation of certain social groups in income, existential minimum, etc.). Furthermore, some economies can have a high GDP per capita due to an abundance of natural resources with high prices in the world's economy, but they can still be undeveloped or economically underdeveloped. If they use these natural benefits for economic growth, they can easily reach the level of economic development of developed countries. However, this does not always happen, and very often, the situation is quite the opposite.

Based on the World Bank 2012 classification, Moldova and Albania belong to the group of countries with a low-middle income; Bosnia and Herzegovina, Bulgaria, Macedonia, Montenegro, Romania and Serbia have an upper-middle income, while Croatia belongs to the group with a high income. Most of the nine selected countries have emerging or developing economies. If the World Bank classification is analysed, the countries' rankings are almost the same for the observed period (Table 1).

Table 1. GNI per capita, Atlas method (current US\$) and ranking of the selected countries, 2007-2012

\begin{tabular}{lcccccccccccc}
\hline & 2007 & $\begin{array}{c}\text { Rank } \\
07\end{array}$ & 2008 & $\begin{array}{c}\text { Rank } \\
08\end{array}$ & 2009 & $\begin{array}{c}\text { Rank } \\
09\end{array}$ & 2010 & $\begin{array}{c}\text { Rank } \\
10\end{array}$ & 2011 & $\begin{array}{c}\text { Rank } \\
11\end{array}$ & $\begin{array}{c}2012 \\
\text { Rank } \\
12\end{array}$ \\
\hline Albania & 3,310 & 8 & 3,850 & 8 & 4,030 & 8 & 4,040 & 8 & 4,050 & 8 & 4,030 & 8 \\
\hline $\begin{array}{l}\text { Bosnia and } \\
\text { Herzegovina }\end{array}$ & 3,730 & 6 & 4,460 & 6 & 4,660 & 6 & 4,640 & 6 & 4,680 & 7 & 4,750 & 6 \\
\hline Bulgaria & 4,530 & 3 & 5,700 & 3 & 6,080 & 4 & 6,320 & 4 & 6,640 & 4 & 6,840 & 4 \\
\hline Croatia & 12,200 & 1 & 13,790 & 1 & 13,700 & 1 & 13,550 & 1 & 13,750 & 1 & 13,490 & 1 \\
\hline $\begin{array}{l}\text { Macedonia, } \\
\text { FYR }\end{array}$ & 3,390 & 7 & 4,130 & 7 & 4,450 & 7 & 4,580 & 7 & 4,710 & 6 & 4,620 & 7 \\
\hline Moldova & 1,160 & 9 & 1,500 & 9 & 1,570 & 9 & 1,820 & 9 & 1,980 & 9 & 2,070 & 9 \\
\hline Montenegro & 4,200 & 5 & 5,610 & 4 & 7,030 & 3 & 6,670 & 3 & 7,210 & 3 & 7,220 & 3 \\
\hline Romania & 6,430 & 2 & 8,050 & 2 & 8,250 & 2 & 8,010 & 2 & 8,230 & 2 & 8,820 & 2 \\
\hline Serbia & 4,370 & 4 & 5,360 & 5 & 5,740 & 5 & 5,550 & 5 & 5,530 & 5 & 5,280 & 5 \\
\hline
\end{tabular}

Note: In the Table ranking is done among the selected countries, and the authors have ranked them from 1 (the most developed) to 9 (the least developed).

Source: The World Bank Data (2012). 


\subsection{The UNDP classification - the Human Development Index (HDI)}

Since 1993, The United Nations Development Programme (UNDP) has used a specific composite formula for ranking countries in its annual report. The UN Human Development Index (HDI) is a socio-economic measure that ranks countries into four tiers of human development. The Human Development Index (HDI) contains three dimensions (health, education and living standards) and five indicators (life expectancy at birth, mean years of schooling, expected years of schooling, adult literacy rate and gross national income per capita) (UNDP 2012). That is how the HDI measures the average accomplishments of countries in three main areas of human life: health, education and standard of living (Deb 2015). According to Hicks (1997), "HDI attempts to encompass three important spheres of socioeconomic life, each of which captures a different dimension of economic choices for well-being". The base for calculating the HDI are three development goals: longevity measured by life expectancy at birth, knowledge measured as the weighted average in adult literacy and years of schooling, i.e. education, and living standards, the real gross domestic product per capita. The index ranks all the countries on a scale of 0 (low human development) to 1 (very high human development). Countries are divided into development groups according to HDI values in the following way: low human development $(0.0$ to 0.499$)$, middle human development ( 0.50 to 0.799$)$, high human development (0.8 to 0.899) and very high human development (0.9 to 1.0) (Todaro, Smith 2009). One hundred and eighty six countries were ranked by this index in 2012 .

Longevity, knowledge and standard of living are the basic dimensions of human welfare. Of course, the composite indices have their advantages and disadvantages. As a summary measure of basic human development, the HDI represents a multidimensional concept instead of a large number of different and independent indicators. In addition, the HDI is important from the aspect of normative economics as support for policy makers (Lamande et al. 2004). The simplification and subjectivity of dimensions, indicators and their weights are specified as the main deficiencies. Furthermore, the mixture of stock and flow variables cannot be neglected. Although stocks (a quantity measured at a specific point in time) and flows (quantities measured per unit of time) are often interrelated, in certain cases they represent an inappropriate combination of variables.

If we compare the HDI and GNI per capita, we notice that the greater the income, the higher the HDI. The HDI relates to the level of income per capita. The countries of Southeast Europe have a low income per capita. In this region, Moldova has the lowest GNI per capita of about $\$ 2,100$, while Croatia has the highest of about $\$ 14,000$. According to the achieved income, this group of countries is behind the developed countries. Among the 186 countries that were analysed and ranked by UNDP, Southeast European countries hold the $47^{\text {th }}$ to $78^{\text {th }}$ positions, while Moldova holds the lowest $\left(113^{\text {th }}\right)$ position. According to the HDI value for 2012, only Croatia has high human development, while the other countries have middle human development. By analysing each of the HDI indicators, it is clear that all the countries made some progress (Table 2). 
Table 2. HDI and ranking of the selected Southeast European countries, 2007-2012

\begin{tabular}{lcccccccccccc}
\hline & 2007 & $\begin{array}{c}\text { Rank } \\
07\end{array}$ & 2008 & $\begin{array}{c}\text { Rank } \\
08\end{array}$ & 2009 & $\begin{array}{c}\text { Rank } \\
09\end{array}$ & 2010 & $\begin{array}{c}\text { Rank } \\
10\end{array}$ & 2011 & $\begin{array}{c}\text { Rank } \\
11\end{array}$ & $\begin{array}{c}2012 \\
\text { Rank } \\
12\end{array}$ \\
\hline Albania & 0.737 & 6 & 0.741 & 6 & 0.743 & 6 & 0.746 & 6 & 0.748 & 6 & 0.749 & 6 \\
\hline $\begin{array}{l}\text { Bosnia and } \\
\text { Herzegovina }\end{array}$ & 0.729 & 7 & 0.734 & 7 & 0.733 & 8 & 0.733 & 8 & 0.734 & 8 & 0.735 & 8 \\
\hline Bulgaria & 0.766 & 4 & 0.773 & 4 & 0.774 & 4 & 0.778 & 4 & 0.78 & 4 & 0.782 & 4 \\
\hline Croatia & 0.798 & 1 & 0.801 & 1 & 0.8 & 1 & 0.804 & 1 & 0.804 & 1 & 0.805 & 1 \\
\hline $\begin{array}{l}\text { Macedonia, } \\
\text { FYR }\end{array}$ & 0.719 & 8 & 0.734 & 8 & 0.734 & 7 & 0.736 & 7 & 0.738 & 7 & 0.74 & 7 \\
\hline Moldova & 0.644 & 9 & 0.65 & 9 & 0.645 & 9 & 0.652 & 9 & 0.657 & 9 & 0.66 & 9 \\
\hline Montenegro & 0.775 & 2 & 0.784 & 2 & 0.784 & 2 & 0.787 & 2 & 0.791 & 2 & 0.791 & 2 \\
\hline Romania & 0.772 & 3 & 0.784 & 3 & 0.784 & 3 & 0.783 & 3 & 0.784 & 3 & 0.786 & 3 \\
\hline Serbia & 0.76 & 5 & 0.765 & 5 & 0.766 & 5 & 0.767 & 5 & 0.769 & 5 & 0.769 & 5 \\
\hline
\end{tabular}

Note: In the Table ranking is done among the selected countries, and the authors have arranged them from 1 (the highest human development) to 9 (the lowest human development).

Source: UNDP (2012).

\subsection{The I-distance method}

The I-distance method is a multivariate statistical analysis method, developed by Ivanovic (1973). The method takes into consideration many heterogeneous indicators in order to obtain a synthetic indicator that will determine the rank of an entity. Selection of indicators is the first step. A different order of indicators could show different rankings and the indicators should be ranked according to their importance. The first attribute is the most important one, while the last one has the smallest influence on I-distance.

Let $X=\left\{x_{1 s}, x_{2 s}, \ldots, x_{k s}\right\}$ be the set of indicators, ordered by their importance, for the unit $P s$. The I-distance for the units $P_{r}$ and $P_{s}$, is given by:

$$
D(r, s)=\sum_{i=1}^{k} \frac{\left|d_{i}(r, s)\right|}{\sigma_{i}} \prod_{j=1}^{i-1}(1-r j i .12 \ldots j-1),
$$

where $d_{i}(r, s)=x_{i r}-x_{i s}, i \in\{1, \ldots, k\}$ is the discriminate effect, e.g. the difference between the values of attribute $x_{i}$ for $P_{r}$ and $P_{s}$. $\sigma_{i}$ is the standard deviation of $x_{i}$, and $r_{j i .12 \ldots . .1}$ is the partial correlation coefficient for $x_{i}$ and $x_{j},(j<i)$. The I-distance is calculated through the following steps (Ivanovic 1973; Mihailovic et al. 2009; Dobrota et al. 2012):

- Calculate the value of the discriminate effect of attribute $x_{1}$, (the most significant indicator);

- Add the value of the discriminate effect of $x_{2}$ which is not covered by $x_{1}$;

- Add the value of the discriminate effect of $x_{3}$ which is not covered by $x_{1}$ and $x_{2}$;

- Repeat the procedure for all indicators.

The squared I-distance, defined by (2), is used in order to eliminate the negative values of partial correlation coefficients: 


$$
D(r, s)=\sum_{i=1}^{k} \frac{\left|d_{i}^{2}(r, s)\right|}{\sigma i} \prod_{j=1}^{i-1}\left(1-r^{2} j i .12 \ldots j-1\right) .
$$

In order to rank the elements in the observed set using I-distance methodology, it is necessary to fix one unit as a referent. The unit with minimal value for each indicator is the referent unit in the research presented here. The ranking of the units in the set is based on the calculated distance from the referent unit (Bulajic et al. 2010). Higher values of the I-distance method show that the observed country is on a higher level of development.

The I-distance method will be used in order to rank the selected Southeast European countries (Albania, Bosnia and Herzegovina, Bulgaria, Croatia, Macedonia, Moldova, Montenegro, Romania and Serbia) for the period between 2007 and 2012. The chosen indicators are similar to those used for calculating the HDI in order to identify any differences in ranking by the different methods. Additionally, some government finance indicators are also included due to the observed period following the economic crisis. The socio-economic indicators or variables used for calculating I-distance in this paper are: the GDP per capita (current US\$), general government gross debt (\% of GDP), general government net lending/borrowing ( $\%$ of GDP), total debt services ( $\%$ of exports of goods, services and primary income), inflation, consumer prices (annual \%), unemployment, total (\% of total labour force), Internet users (per 100 people), life expectancy at birth, total (years), and mean years of schooling of adults (years).

The sources for the selected variables or indicators are the World Bank, IMF World Economic Outlook and UNDP databases. The software used to calculate the I-distance is SPSS. The squared I-distance is calculated for all the years from 2007 to 2012.

By applying the chosen indicators within the I-distance method, we have determined the value of the I-distance method, as well as the ranks for the specific year, which are presented in Table 3.

Table 3. Ranking countries by I-distance method for the selected Southeast European countries, 2007-2012

\begin{tabular}{lcccccccccccc}
\hline & $\mathrm{I}_{-}^{2} 07$ & $\begin{array}{c}\text { Rank } \\
07\end{array}$ & $\mathrm{I}^{2}{ }^{0} 0$ & $\begin{array}{c}\text { Rank } \\
08\end{array}$ & $\mathrm{I}^{2}$ 09 & $\begin{array}{c}\text { Rank } \\
09\end{array}$ & $\mathrm{I}^{2} \_10$ & $\begin{array}{c}\text { Rank } \\
10\end{array}$ & $\mathrm{I}^{2} \_11$ & $\begin{array}{c}\text { Rank } \\
11\end{array}$ & $\mathrm{I}^{2}{ }^{2} 12$ & $\begin{array}{c}\text { Rank } \\
12\end{array}$ \\
\hline Albania & 8.45 & 6 & 8.69 & 5 & 10.66 & 6 & 9.1 & 6 & 9.66 & 4 & 10.83 & 3 \\
\hline $\begin{array}{l}\text { Bosnia and } \\
\text { Herzegovina }\end{array}$ & 15.72 & 2 & 2.85 & 9 & 6.6 & 8 & 5.27 & 8 & 3.46 & 8 & 6.38 & 6 \\
\hline Bulgaria & 11.48 & 5 & 19.89 & 1 & 27.07 & 1 & 17.62 & 2 & 16.56 & 1 & 17.6 & 1 \\
\hline Croatia & 15.53 & 3 & 17.12 & 2 & 24.15 & 2 & 17.72 & 1 & 15.72 & 2 & 14.26 & 2 \\
\hline $\begin{array}{l}\text { Macedonia, } \\
\text { FYR }\end{array}$ & 7.12 & 7 & 6.82 & 7 & 13.8 & 4 & 10.91 & 5 & 4.21 & 7 & 4.75 & 7 \\
\hline Moldova & 5.7 & 8 & 10.89 & 4 & 3.79 & 9 & 11.36 & 3 & 10.16 & 3 & 7.56 & 5 \\
\hline Montenegro & 14.06 & 4 & 8.6 & 6 & 15.01 & 3 & 11.33 & 4 & 5.91 & 6 & 4.1 & 8 \\
\hline Romania & 17.09 & 1 & 15.7 & 3 & 13.58 & 5 & 8.52 & 7 & 8.94 & 5 & 8.01 & 4 \\
\hline Serbia & 2.53 & 9 & 3.64 & 8 & 9.13 & 7 & 3.89 & 9 & 1.53 & 9 & 0.96 & 9 \\
\hline
\end{tabular}


The $i^{2}$ Distance values obtained for the observed countries and each year can be analysed in order to perceive the differences in the level of development. The values of $\mathrm{i}^{2}$ Distance show the differences between countries. In the countries' rankings, there are similarities from year to year, with the exception of the rankings for Bosnia and Herzegovina, Bulgaria and Croatia (2007), Macedonia and Serbia (2009), Romania (2010) and Albania and Montenegro (2012). Furthermore, Moldova has a different rank from year to year. The rankings of these countries in the above specified years show the greatest number of dissimilarities in comparison to other years.

All the selected countries of Southeast Europe have very similar characteristics. In this sense, they are all focused on creating market-based economies, implementing structural and institutional reforms and establishing macroeconomic stability. Despite the improved situation, these small economies remain uncompetitive due to inadequate harmonisation with European and international standards. However, there are differences among them. The small differences in the I-distance values for the countries prove a similarity in their economic development. From the data given in Table 3 it is clear that the differences in the transition processes for the analysed countries are decreasing as the countries are approaching the European Union and bringing an end to the carried-out reforms.

\section{Results and discussion}

The results achieved by applying the I-distance method were compared to the results of the HDI and GNI per capita. Table 4 shows the comparison of the development levels and rankings according to the GNI per capita, HDI and $i^{2}$ Distance for the selected Southeast European countries for the period from 2007 to 2012.

A limited number of indicators were taken as the basis for the I-distance method. The constraints of the study stem from the fact that some of the indicators for SEE countries were not available in the relevant databases, but also from the limitations of the research method itself. The I-distance method does not support a large number of indicators for a smaller number of entities i.e. countries. Even so, the assumption was that research into the economic development and countries' rankings of a few selected countries from the SEE region would be better and more reliable if the I-distance method were applied because it includes a broad range of selected national accounts, monetary, government finance, economic growth, liquidity and social indicators. The assumption was that a synthetic indicator obtained by the I-distance method would show different countries' rankings more clearly than the other two methods. However, the assumption was not totally validated.

The ranking is similar with all the mentioned methods. In the countries' rankings, both by HDI and by GNI per capita, there are only small differences from year to year, and there is a continuous correlation. In terms of HDI, the ranking is the same for all the observed countries. There is only a small variation in 2007 and 2008 (Macedonia and Bosnia and Herzegovina). By GNI per capita, it varies slightly in 2007 (Serbia), in 2007 and 2008 (Bulgaria and Montenegro) and in 2011 (Macedonia and Bosnia and Herzegovina). The HDI highly correlates with GNI per capita. The I-distance values show more differences 
between the countries than the HDI or GNI per capita. The I-distance values vary during the observed period.

There are differences in the countries' rankings for the observed years. For example, when comparing all three methods, Croatia has the highest rank for all the years under analysis. According to the I-distance method, Croatia was ranked as first (2010), second (2008, 2009, 2011 and 2012) and as third (2007), while in terms of GNI per capita and the HDI it is always first. Furthermore, if the results or ranks of all three methods are compared, the most drastic inconsistencies are to be found in Bulgaria, Serbia, Macedonia, Moldova, Montenegro and Romania. The position of Albania, Bulgaria (except for 2007), Macedonia (only for 2009 and 2010), and Moldova (with the exception of 2007 and 2009) are better when ranked using the I-distance method, while the position of Serbia is lower with the I-distance method than with the other two. Economic reforms, meeting the requirements for accession to the EU and the impact of the economic crisis are the main factors that influenced the development of the SEE countries and their various ratings by all three methods. Moreover, the ranking in 2007 shows the greatest deviation compared with the following years. Both Bosnia and Herzegovina and Romania achieved good economic performance thanks to an investment boom, while the investment boom in Bulgaria did not result in GDP growth. Socio indicators do not have much impact on development and rankings because they did not change during the observed period. All differences stem from economic indicators, especially from external and public debt, investment and current account deficit. All SEE countries are following a similar path towards establishing a market based economy and convergence with the EU. To sum up, the pace of carrying out reforms and the fulfilment of EU accession criteria impact on the level of economic development.

By observing the data used to calculate the I-distance method values it is possible to find an explanation for the rank differences. In the observed period Bulgaria has the highest rank according to the I-distance method values (rank 1and 2), while in terms of the GNI per capita and HDI it has a much lower one (rank 4). Bulgaria has a lower rank in 2007 when measured by the I-distance method (rank 5) than in the other years. Bulgaria enjoyed an investment boom until 2007. However, the effects of the investment boom were delayed and although the growth rate was initially stable, it went on to decelerate in the following years. During 2007 and 2008, inflation was high, but this rate subsequently dropped. Unemployment rose after 2008 as did exports after 2009. These are the possible explanations as to why Bulgaria was ranked higher from 2008 to 2012.

In 2007, Bosnia and Herzegovina's general government gross debt stood at $18.7 \%$ of the GDP, while in 2012 it rose to $44.6 \%$. Moreover, Bosnia and Herzegovina had a fiscal surplus in 2007 and low external debt (58.7\% of the GDP). The influence of those indicators brought Bosnia and Herzegovina a rank of 2nd place in 2007. Until 2007, Bosnia and Herzegovina had enjoyed sound macroeconomic policies, macroeconomic stability, accelerated structural reforms and a favourable external environment. However, in 2008, this changed when Bosnia and Herzegovina signed a Stabilization and Association Agreement with the EU, which led to economic imbalance. Capital inflows and credit expansion impacted on domestic demand. The consequences of the domestic demand boom were the rise of inflation (from 1.5\% in 2007 to $7.4 \%$ in 2008), and a higher general government 
gross debt with fiscal and current account deficits. Moreover, the influence of the economic crisis on the Bosnian economy was significant. Those factors influence the Bosnian rank and explain why in 2007, Bosnia and Herzegovina ranked $2^{\text {nd }}$, while in the following years it ranked $9^{\text {th }}$ and $8^{\text {th }}$.

Serbia has a lower rank according to the I-distance method (2007-2012) than when measured by the other ranking methods. The explanation for this great deviation obtained by the I-distance method can be found in economic indicators - low economic growth, high unemployment, lack of capital, low fiscal performance, low investment level, low external liquidity, high insolvency and high indebtedness. There have been some improvements such as a slight increase in exports (after 2008). Serbia is lagging behind in carrying out economic reforms and economic performance is not as good as in the other SEE countries.

Montenegro has a better rank according to the GNI per capita and HDI than by the I-distance method. According to the I-distance method, Montenegro had a ranking of $8^{\text {th }}$ in 2012. Since the economic crisis, economic output has almost recovered and financial stability has been achieved. However, public debt has risen significantly (68.3\% of the GDP in 2012).

In 2011 and 2012, Albania had a better rank according to the I-distance method than by the HDI and GNI per capita. Albania experienced financial instability until 2009, which is the reason for the low level of development and the low ranking. In 2011 and 2012, Albania enjoyed improved economic performance thanks to a fiscal stimulus and a sound monetary policy. Due to economic policies, a significant fall in output was avoided, low inflation and banking system stability were achieved, exports increased, spurred mostly by the export of electricity, and economic activity expanded.

Moldova, one of the poorest countries, ranked $3^{\text {rd }}\left(2010\right.$ and 2011) and $4^{\text {th }}(2008)$ by the I-distance method, while the GNI per capita and HDI ranking is $9^{\text {th }}$. In 2009, Moldova experienced a decline in economic growth. In that year, the IMF approved arrangements and the free trade area with the EU brought certain benefits. By 2012, Moldova had FDI inflows, credit and remittances, which increased the GDP and exports and resulted in a fall in unemployment, but also a rise in the current account deficit and inflation. Furthermore, it carried out reforms in the area of social assistance, health and education, energy and competitions. This served to increase the number of internet users.

In addition to the high correlation in the rankings obtained by the application of different methods, it can also be noticed that the I-distance method provides both an objective insight into the socioeconomic development of the observed countries and a presentation of all the results by a single indicator, calculated from the values of several other indicators. The I-distance method has confirmed that there are differences in the development levels of the observed countries. Bulgaria and Croatia are the most developed. Such a ranking is not surprising because these two countries (and Romania) are members of the EU, while the others are still carrying out reforms in order to harmonise their indicators with those of the EU and to meet the conditions of EU membership. 


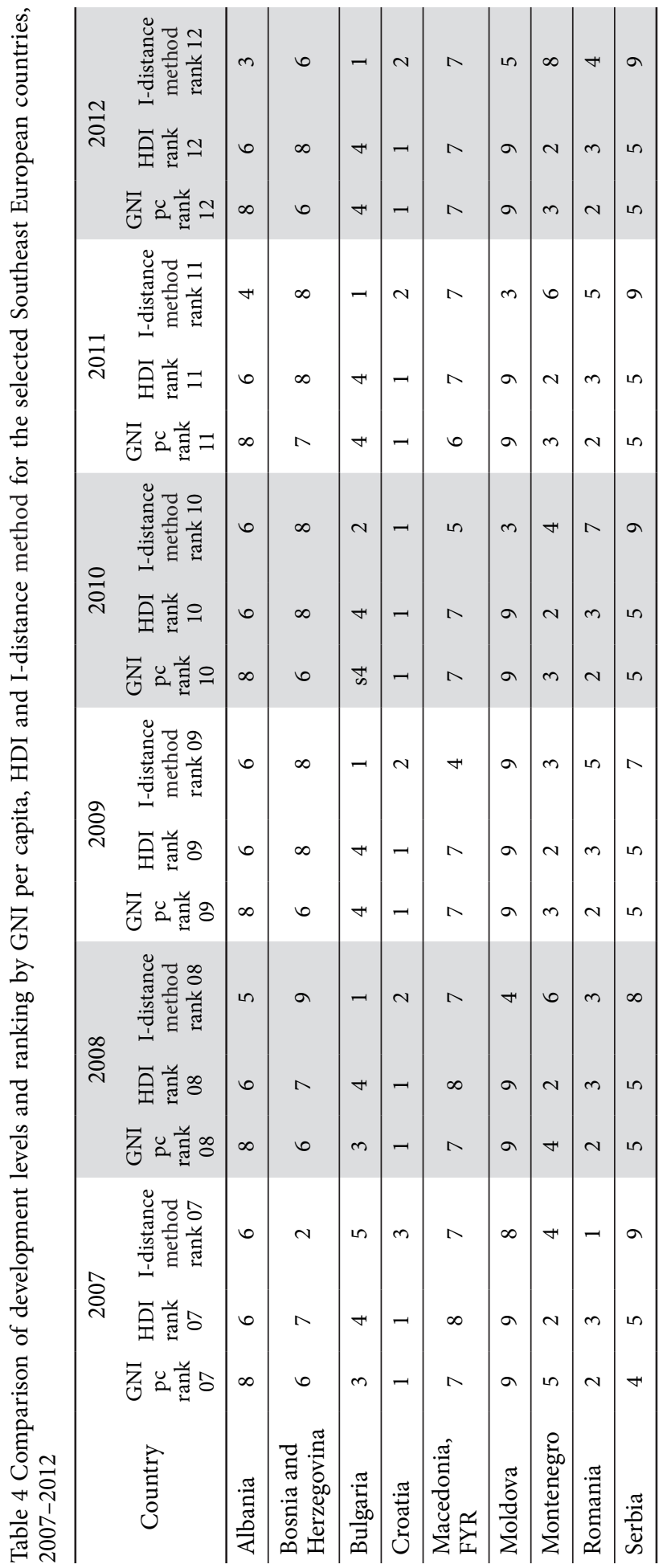




\section{Conclusions}

The analysis of a country's welfare rests, above all, on a combination of economic and social indicators. Some important macroeconomic studies are concerned with countries' rankings and the examination of their economic and social parameters. The aim of this paper is to compare three methods of ranking nine Southeast European countries in order to measure their economic development and to rank them. Two widely-used indicators for measuring development; the GDP per capita and HDI, are criticised for their imperfections and limitations (Stiglitz et al. 2009a; van den Bergh 2009; Grimm et al. 2008; Norberg 2010; Luque et al. 2016). Many researchers have been trying to improve methodology or to find a new one, as well as a new indicator that will represent a good measure of countries' welfare. In this paper, the I-distance method of multivariate statistical analysis (Ivanovic 1973) has been used. The I-distance method takes into consideration many heterogeneous indicators in order to gain a synthetic indicator that will determine the rank of an entity. However, the I-distance method also has its limitations. This method cannot support a large number of variables for a few entities. The results of this research show that the countries' development rankings based on the I-distance method are not so different from those made by international organisations. However, some differences in ranking occur in all the methods. There are small differences from year to year in terms of the HDI and GNI per capita, while the I-distance method values show more differences between the countries. The I-distance method values vary during the observed period. The greatest differences in ranking are in 2007, 2011 and 2012. The ranking in 2007 is the result of previous economic policies, while during 2011 and 2012 most of the countries had recovered after the economic crisis. Differences exist because not all the countries began economic reforms at the same time and they are now at different stages in the process of EU integration. This research was done in order to fill a gap in the analysis of the development and ranking of SEE countries. Further work could be a comparative analysis of the development of EU members and SEE countries using the I-distance method. Depending on the available data, the indicators could be oriented more towards government finance indicators.

\section{Acknowledgements}

The authors are grateful to anonymous reviewers for their helpful comments and suggestions.

\section{References}

Acemoglu, D. 2010. Theory, general equilibrium, and political economy in development economics, Journal of Economic Perspectives 24(3): 17-32. https://doi.org/10.1257/jep.24.3.17

Aruoba. S. B.; Diebold, F. X.; Nalewaik, J.; Schorfheide, D. S. 2016. Improving GDP measurement: a measurement-error perspective, Journal of Econometrics 191(2): 384-397. https://doi.org/10.1016/j.jeconom.2015.12.009

Babanassis, S. 2003. Long-term economic development trends in South-Eastern Europe (1850-2003), South Eastern Europe Journal of Economics 1: 19-40. 
Bartlett, W. 2008. Europe's troubled region: economic development, institutional reforms and social welfare in the western Balkans. Routledge studies in development economics. Abingdon, UK: Routledge. https://doi.org/10.4324/9780203644898

BenYishay, A.; Grosjean, P. 2014. Initial endowments and economic reform in 27 post-socialist countries, Journal of Comparative Economics 42(4): 892-906. https://doi.org/10.1016/j.jce.2014.04.008

Blancard, S.; Hoarau, J. F. 2013. A new sustainable human development indicator for small island developing states: a reappraisal from data envelopment analysis, Economic Modelling 30: 623-635. https://doi.org/10.1016/j.econmod.2012.10.016

Blanchard, O. 1997. The economics of post-communist transition. Oxford, UK: Oxford Scholarship Online.

Bulajic, M.; Kragulj, D.; Jednak, S. 2010. Macroeconomic flows in CEFTA countries, Computational Intelligence in Business and Economics 3: 533-540. https://doi.org/10.1142/9789814324441_0063

Cachanosky, N. 2009. GPD vs EVA as an economic indicator [online]. MPRA Paper No.15262 [cited 4 January 2014]. Available from Internet: http://mpra.ub.uni-muenchen.de/15262/1/MPRA_paper_15262.pdf

Damijan Joze, P.; Knell, M.; Majcen, B.; Rojec, M. 2003. The role of FDI, R\&D accumulation and trade in transferring technology to transition countries: evidence from firm panel data for eight transition countries, Economic System 27(2): 189-204. https://doi.org/10.1016/S0939-3625(03)00039-6

Davidson, E. A. 2000. You can't eat GNP: economics as if ecology mattered. Perseus, Cambridge, MA: Perseus Pub.

Deb, S. 2015. The human development index and its methodological refinements, Social Change 45 (1): 131-136. https://doi.org/10.1177/0049085714561937

De Melo, M.; Denizer, C.; Gelb, A.; Tenev, S. 1997. Circumstance and choice: the role of initial conditions and policies in transition economies. The World Bank.

Delgado, M.; Porter, E. M.; Stern, S. 2012. Cluster, convergence and economic performance [online]. Working paper 18250. National Bureau of economic research [cited 5 January 2014]. Available from Internet: http://www.nber.org/papers/w18250.pdf

Delic, M.; Kragulj, D. 2005. Objectives of macroeconomics as the basis for clustering of countries in integrated Europe, in The $7^{\text {th }}$ Balkan Conference on Operational Research "BACOR 05", May 2005, Constanta, Romania.

Dobrota, M.; Jeremic, V.; Markovic, A. 2012. A new perspective on the ICT development index, Information Development 28: 271-280. https://doi.org/10.1177/0266666912446497

Dowrick, S.; Dunlop, Y.; Quiggin, J. 2003. Social indicators and comparisons of living standards, Journal of Development Economics 70: 501-529. https://doi.org/10.1016/S0304-3878(02)00107-4

EBRD. 2006. Transition Report 2006. Finance in Transition. European Bank for Reconstruction and Development.

Eckehard, R. 2011. Competitiveness rankings of European countries - How much do they tell us?, Intereconomics 46(2): 82-90. https://doi.org/10.1007/s10272-011-0368-5

Fagerberg, J.; Srcholec, M. 2008. National innovation systems, capabilities and economic development, Research Policy 37: 1417-1435. https://doi.org/10.1016/j.respol.2008.06.003

Falcetti, E.; Lysenko, T.; Snafey, P. 2006. Reforms and growth in transition: re-ecaming the evidence, Journal of Comparative Economics 34: 421-445. https://doi.org/10.1016/j.jce.2006.06.008

Giroud, A.; Jindra, B.; Marek, P. 2012. Heterogeneous FDI in transition economies - a novel approach to assess the developmental impact of backward linkages, World Development 40(11): 2206-2220. https://doi.org/10.1016/j.worlddev.2012.03.018

Grimm, M.; Harttge, K.; Klasen, S.; Misselhorn, M. 2008. A human development index by income groups, World Development 36(12): 2527-2546. https://doi.org/10.1016/j.worlddev.2007.12.001 
Hicks, A. D. 1997. The inequality-adjusted Human Development Index: a constructive proposal, World Development 24(8): 1283-1298. https://doi.org/10.1016/S0305-750X(97)00034-X

Høyland, B.; Moene, K.; Willumsen, F. 2012. The tyranny of international index rankings, Journal of Development Economics 97(1): 1-14. https://doi.org/10.1016/j.jdeveco.2011.01.007

Iamsiraroj, S.; Ulubasoglu, M. A. 2015. Foreign direct investment and economic growth: a real relationship or wishful thinking?, Economic Modelling 51: 200-213.

https://doi.org/10.1016/j.econmod.2015.08.009

Ivanovic, B. 1973. A method of establishing a list of development indicators. United Nations educational, scientific and cultural organization, Paris.

Ivanovic, B. 1977. Classification theory. Institute for Industrial Economics, Belgrade.

Iwasaki, I.; Tokunaga, M. 2014. Macroeconomic impacts of FDI in transition economies: a meta-analysis, World Development 61: 53-56. https://doi.org/10.1016/j.worlddev.2014.03.022

Josifidis, K.; Dragutinovic Mitrovic, R.; Ivancev, O. 2012. Heterogeneity of growth in the West Balkans and Emerging Europe: a dynamic panel data model approach, Panoeconomicus 2: 157-183. https://doi.org/10.2298/PAN1202157J

Khayyat, N. T.; Lee, J. D. 2016. A measure of technological capabilities for developing countries, Technological Forecasting and Social Change 92: 210-223. https://doi.org/10.1016/j.techfore.2014.09.003

Kostoska, O.; Mitrevski, P. 2008. Estimating the FDI impact on economic growth and export performances of the European economies in transition, Revista Tinerior Economisti (The Young Economists Journal) 1(11): 115-126.

Kovacevic, R. 2004. Foreign direct investment as a factor of growth - the experience of European Union countries, Medjunarodni problemi 56(4): 409-446 (in Serbian).

Kragulj, D. 2005. European integration and transition processes. Kragulj, Belgrade, Serbia (in Serbian).

Kragulj, D. 2012. Economics - Basis of microeconomic and macroeconomic analysis. Belgrade, Serbia (in Serbian).

Kubiszewski, I.; Costanza, R.; Franco, C.; Lawn, P.; Talberth, J.; Jackson, T.; Aylmer, C. 2013. Beyond GDP: measuring and achieving global genuine progress, Ecological Economics 93: 57-68. https://doi.org/10.1016/j.ecolecon.2013.04.019

Kumhof, M.; Laxton, D. 2013. Simple fiscal policy rules for small open economies, Journal of International Economics 91: 113-127. https://doi.org/10.1016/j.jinteco.2013.05.002

Lamande, V.; Samson, I.; Vinokurov, E. 2004. Measuring regional economic development in Russia: the case of the Kalinigrad oblast, European Urban and Regional Studies 11: 71-80 [online], [cited 6 January 2014]. Available from Internet: http://eur.sagepub.com/content/11/1/71.full.pdf+html

Luque, M.; Perez-Moreno, S.; Rodriguez, B. 2016. Measuring human development: a multi-criteria approach, Social Indicators Research 125: 713-733. https://doi.org/10.1007/s11205-015-0874-0

Malul, M.; Hadad, Y.; Ben-Yair, A. 2009. Measuring and ranking of economic, environmental and social efficiency of countries, International Journal of Social Economics 36(8): 832-843. https://doi.org/10.1108/03068290910967109

Michaelson, J.; Abdallah, S.; Steuer, N.; Thompson, S.; Marks, N.; Aked, J.; Cordon, C.; Potts, R. 2009. National Accounts of Well-being: bringing real wealth onto the balance sheet [online]. NEF (the New Economics Foundation), London [cited 6 January 2014]. Available from Internet: http://www.nationalaccountsofwellbeing.org/learn/download-report.html

Mihailovic, N.; Bulajic, M.; Savic, G. 2009. Ranking of banks in Serbia, Yugoslav Journal of Operations Research 19: 323-334.

Norberg, J. 2010. GDP and its enemies: the questionable search for a happiness index, European View 9(2): 281-282. https://doi.org/10.1007/s12290-010-0143-1 
Nuti, M. D. 2009. The impact of the global crisis on transition economies, Economic Annals 54(181): 7-20. https://doi.org/10.2298/EKA0981007N

Pérez-Ortiz, M.; de la Paz-Marín, M.; Gutiérrez, P. A.; Hervás-Martínez, C. 2014. Classification of EU countries' progress towards sustainable development based on ordinal regression techniques, Knowledge-Based Systems 66: 178-189. https://doi.org/10.1016/j.knosys.2014.04.041

Petrakos, G.; Kallioras, D.; Anagnostou, A. 2011. Regional convergence and growth in Europe: understanding patterns and determinants, European Urban and Regional Studies 18(4): 375-391. https://doi.org/10.1177/0969776411407809

Radojicic, Z.; Isljamovic, S.; Petrovic, N.; Jeremic, V. 2012. A novel approach to evaluating sustainable development, Problemy ekorozwoju 7: 81-85.

Radulescu, A. 2012. The Balkans: between economic crisis and European integration, Financial Studies 16: $129-146$.

Sagar, D. A.; Najam, A. 1998. The human development index: a critical review, Ecological Economics 25(3): 249-264. https://doi.org/10.1016/S0921-8009(97)00168-7

Sanfey, P.; Teksoz, U. 2007. Does transition make you happy?, Economics of Transition 15(4): 707-731. https://doi.org/10.1111/j.1468-0351.2007.00309.x

Stiglitz, J.; Sen. A.; Fitoussi, J. P. 2009a. The Measurement of economic performance and social progress revisited - reflections and overview. Working paper of Commission on the Measurement of Economic Performance and Social Progress (CMEPSP) [online], [cited 5 January 2014]. Available from Internet: http://www.stiglitz-sen-fitoussi.fr/documents/overview-eng.pdf

Stiglitz, E. J.; Sen, A.; Fitoussi, J. P. 2009b. Report by the Commission on the Measurement of Economic Performance and Social Progress [online], [cited 5 January 2014]. Available from Internet: http:// www.novorumo.info/economia/stoglitzetal.pdf

Todaro, P. M.; Smith, S. C. 2009. Economic development. 10th ed. Addison-Wesley, Person Education.

The World Bank. 2012. World development indicators [cited 3 January 2014]. Available from Internet: https://issuu.com/world.bank.publications/docs/9781464801631

Tvrdon, M.; Skokan, K. 2011. Regional disparities and the ways of their measurement: the case of the visegrad four countries, Technological and Economic Development of Economy 17(3): 501-518. https://doi.org/10.3846/20294913.2011.603485

UNDP. 2012. Human development data [online], [cited 3 January 2014]. Available from Internet: http:// hdr.undp.org/en/data

van den Bergh Jeroen, C. J. M. 2009. The GDP paradox, Journal of Economic Psychology 30: 117-135. https://doi.org/10.1016/j.joep.2008.12.001

Wu, P. C.; Fan, C. W.; Pan, S. C. 2014. Does Human Development Index provide rational development rankings? Evidence from efficiency rankings in super efficiency model, Social Indicators Research 116(2): 647-658. https://doi.org/10.1007/s11205-013-0285-Z

Xu, G.; Wang, R. 2007. The effect of Foreign Direct Investment on domestic capital formation, trade, and economic growth in a transition economy: evidence from China, Global Economy Journal 7(2). https://doi.org/10.2202/1524-5861.1198 
Sandra JEDNAK. Doctor, Associate Professor. Department of Economics, Business Planning and International Management. The Faculty of Organizational Sciences, University of Belgrade. She holds a $\mathrm{PhD}$ in Economics from the Faculty of Organizational Sciences, University of Belgrade. She received her BSc and MSc degrees in Economics from Faculty of Economics, University of Belgrade. She has published scientific research papers in international and national monographs, journals and conferences proceedings. Her research focus is on the economic growth and development of SEE countries. Besides, her research interests are Economics of ICT, Knowledge (Based) Economy, Energy Economics, International Economics and Higher Education.

Dragana KRAGULJ. Doctor, Full Professor. Department of Economics, Business Planning and International Management. The Faculty of Organizational Sciences, University of Belgrade. She graduated from the Faculty of Economics, University of Belgrade, where she also got her MSc degree and PhD degree. She was a Head of Department of Economics, Business Planning and International Management from October 2010 to November 2012. Now she is a Head of Centre for Economic and Business Research. She has published two monographs, several editions of different textbooks of Economics and over 100 peer-reviewed papers. The areas of her research interest include macroeconomic problems, prices, market, inflation, economic development, investment, international trade, agriculture, energy economics, process of transition, international economic integrations, the European Union.

Milica BULAJIC. Doctor, Full Professor. Department of Operations Research and Statistics. The Faculty of Organizational Sciences, University of Belgrade. She graduated from Faculty of Mathematics, University of Belgrade in 1981. She received her PhD in 2002 at the Faculty of Organizational Sciences, where she works since 1995, now as a Full Professor for the scientific field of computational statistics. She is engaged in probability theory, statistics, econometric methods, data analysis at the Department of Operations Research and Statistics. She is a member of the Statistical Society of Serbia. She speaks English, Italian and French. 